\title{
The Issues of Spirituality in the Workplace
}

\author{
Pr. Lionel Honoré* \\ University of French Polynesia, BP 6570998702 Faa'a - Tahiti \\ *Corresponding Author: Pr. Lionel Honoré, University of French Polynesia, BP 657098702 Faa'a- \\ Tahiti. Email: lionel.honore@upf.pf
}

\begin{abstract}
Spirituality in the workplace is increasingly accepted and encouraged. The limit that companies often set is that of religion. The employee who personally invests himself in his work and the company's activity can bring his spirituality to work insofar as it is not religious.
\end{abstract}

How can this phenomenon be explained? What meaning can we give it? What are the stakes for employees, companies and performance? This contribution aims to provide answers to these questions based on an analysis of the literature on spirituality and religion at work.

Keywords: Spirituality and Religion at Work, Employment and Labor Relations, Personalization of Involvement, Meaning of Work.

\section{INTRODUCTION}

In her book La condition ouvrière, the French philosopher Simone Weil shares her experience as a laborer in a metallurgical factory in the 1930s. She describes the dreadful mindless days. The desperate struggle to keep up and to survive. The feeling of dehumanization that often grips her. The inability to think not only during the time at the factory but also after when she comes home numb from fatigue. And yet, she writes, in contrast to this simplest expression of the mechanical performance of tasks by individuals reduced to a tool condition, the primary dimension of work is spiritual. It is the privileged activity by which people access transcendence, contribute to something greater than themselves. Today, this spiritual dimension of work is more and more recognized, studied, mobilized and even convened in the work space. It has become very simple to find training for a few hours or days for a person or an entire team to practice spirituality at work. The results of a simple internet search give access to the websites of an impressive number of consultants and trainers as well as a host of press articles praising the merits of the spiritualization of management and professional spaces. The star here seems to be meditation in full consciousness. A Buddhist introspection tool that would be the absolute countermeasure to the stress and meaninglessness of today's organizations. A tool, it must be pointed out, (this seems important since it is emphasized quasi-systematically in the advertising arguments of its promoters) which has been secularized, emptied of its religious substance, to serve the populations of an inevitably secularized Western world. Spirituality in the workplace is therefore in fashion and is invited to enter offices and workshops.

In this article we are interested in how spirituality in the workplace can be taken into account theoretically and practically, and how this consideration sheds light on the functioning of post-modern enterprises and the labor and employment relations that develop there.

Our analysis is based on a review of the scientific literature in management sciences that has addressed issues of spirituality in the workplace. We take up the idea that this notion raises the question of taking into account the intrinsic diversity of people and work. Taking into account this diversity both in the scientific literature and in the practices of companies makes it possible to promote the emergence of a new paradigm to consider the functioning of the company starting from an anthropology which integrates all the dimensions of the human being including his spiritual dimension. However, it also results in an ostracism of the religiosity of employees and a reversal of responsibility that further distorts employment and labor relations within the company. 


\section{SPIRITUALITY AT WORK: A DIVERSITY MANAGEMENT ISSUE?}

After having defined the notion of spirituality as it is taken into account in the scientific literature (1.1), we set out to study which questions raise the links between work and spirituality (1.2). The idea that we defend in this first part is that the main issue related to this notion in the workplace, as it emerges from the study of literature, is that of diversity of people as well as of behavior and its consideration by the functioning of the company and management.

\subsection{Definitions}

The scientific literature on spirituality in the workplace struggles to propose definitions of the term that can serve as a shared starting point (Hyman and Handal 2006). In addition, there is a debate in this literature about the usefulness or not of studying religion and spirituality separately(Cavanaugh 1999, Mitroff and Denton 1999, Mitroff 2003, Markow and Klenke2005, Liu and Robertson 2012, Ayoun 2014). For some authors this distinction is vain because religious behaviors are by nature spiritual. They should therefore be treated as such and not specifically (Bailey 2001, Hicks 2002, Phipps 2012). On the contrary for other authors spiritual and religious practices, even if they overlap, are fundamentally different. They must therefore be approached differently when it comes to studying them and taking them into account in the workspace (McLaughlin 2005, Mitroff and Denton 1999, Mitroff, Denton and Alpaslan 2009, Hayden and Barbuto 2011, Schutte 2016).

For Mitroff and Denton (1999), spirituality refers to a search for the meaning of life and work that is both individual and personal. It is defined by the actor and does not refer to any particular denomination, dogma or teaching. For Ashmos and Duchon (2000) it corresponds for each person to the contribution of the meaning of work and work experience to the construction of the meaning of life. For Giacalone and Jurkiewicz (2003), it refers to the way in which everyone approaches the question of transcendence. Karakas (2010) defines spirituality "as the journey to find a lasting, authentic, meaningful, holistic and profound understanding of the existential self and its relation/interconnection with the sacred and the transcendent. Mitroff and Denton (1990), based on interviews of American executives, define spirituality in the context of their respondents' replies as non-formal, structured or organized; not belonging to a religious denomination; inclusive, universal and timeless; corresponding to a search for the meanings and goals of life; to an awareness of the transcendental and interdependence of everything; to a search for inner peace.

These elements are included in numerous articles focusing on the study of spirituality issuesin the workplace (Mitroff 2003, Karakas 2010, Hayden and Barbuto 2011, Ayoun et al. 2014, Fourie 2014, Schutte 2016). Three elements relating to spirituality stand out in the literature as common to all definitions: the search for the meaning of life and human activity and the relationship to transcendence, the relationship to others and the quest for happiness.

\subsection{The Spiritual Dimension of Work and the Question of Spirituality at Work}

The emergence of the question of the spiritual dimension of work is dated in the last two decades of the twentieth century (Gotsis\&Kortezi 2008, Karakas 2010, Hayden and Barbuto 2011, Fourie 2014, Schutte 2016). It is explained by the evolution of companies (Ashmos and Duchon's 2000, Mitroff and Denton 2000, Driver 2005, Frey and Cohen 2009, Karakas 2010, Hayden and Barbuto 2011), that of work itself (Ashmos and Duchon's 2000, Gotsis and Kortezi 2008, Lambert 2010) as well as the changing conditions of people's involvement in work and the place it takes in their lives (Mitroff and Denton 2000, Lambert 2010).

Thus, some researchers link the rise of the question of spirituality to work with the transformation of companies that has been underway for more than forty years. It would correspond to the emergence of a new paradigm and a questioning of the meaning of the employees' contribution to the company's project. The modern enterprise conceived from a rationalist model would have given way to a postmodern enterprise (Giacalone and Dafna 2000; Harman and Hormann, 1990, Ray and Rinzler 1993, Wheatley 1992, Courpasson and Golsorkhi 2011). One of the key elements that characterize this transformation is the company's relationship to its project (Gomez and Korine 2005). The firm of the industrial era after the Second World War corresponds to an entrepreneurial project which, when it is realized and developed, forms the profession of the company. This project and this profession, as well as the resulting production, identify the company and give it, in a way, its personality. Thus General Motors, Ford, Toyota or Renault are car manufacturers, Wall Mart or Carrefour distributors, IBM a 
computer manufacturer, etc.. In the logic of liberalism, business is a project driven by the entrepreneur, backed by the market and to which people, especially employees, join to help the world progress (Gomez and Korine 2005). However, the transformation of companies since the 1970s and 1980s would have occurred through the transition from a profession economy to a project economy (Ekstedt 1999, Hatch 2018).

The company would no longer be a project. It would have become a project receptacle (Chia 1995, Hatch and Cunlife 2013, Parker \&Burell 2015). It would no longer be so easily identifiable by its profession or a product because it multiplies them and changes them at an increasingly rapid pace (Chia 1995, Burke 2017).

At the same time, with the financialization of the economy, objectives would increasingly be defined in terms of financial performance and shareholder investment enhancement (Van der Zwan 2014, Palley 2016). For the employee, the risk would be a loss of the meaning of his contribution to the company's operations and performance (Dutton and Heaphy 2003, Frost et al. 2006). He would move from a situation in which he contributes to a project (making good cars, boats, planes, providing a service to people, etc.) to another in which he produces financial return through his participation in successive actions at increasingly high rates. This transformation in the meaning of their activity and the risks it represents have been well perceived by companies. Since the eighties they have multiplied initiatives to communicate internally about their project, their culture and their values. Some authors see it as an attempt to give meaning to the contribution of their teams and to employee involvement. For Driver (2005) or Kinjierski and Skrypnek (2004) this approach would however have been undermined by the succession of scandals since the early 2000s (more recently Enron, Parmalat, Volkswagen, etc.) as well as by the insecurity in which restructuring and downsizing initiatives, at least some of them, would place employees (Neal 2000, Kennedy 2001, Fry \& Cohen 2009, Widerszal-Bazyl \& Mockałło 2015). The consequence of these changes would be, for employees, a loss of the meaning of what their work contributes to (Jurkiewicz and Giacalone 2004, Driver 2005, Steenkamp and Basson 2013, Brenner \& al. 2014). Companies would thus no longer be able to meet the transcendental needs of the people they employ (Neal 2000, Kinjierski and Skrypnek 2004).

The second explanation identified in the literature to elucidate the emergence of questions of spirituality in the workplace is linked to the transformation of the ways in which the work itself is organized and carried out. Two main elements are highlighted. The first relates to the collective and relational dimensions of work in post-modern organizations (Jurkiewitcz and Giacalone 2004, Hatch 2018). The second is linked to work organization and management methods that confront employees with a paradoxical situation by asking for their greater involvement and active participation while imposing more constraints on them (Courpasson and Golsorkhi 2011).

In fact, the evolution of organizational modes has made it possible to move from work carried out individually to work centered on collective activity and the team (Hirschhorn 1998, Cooper 2015). Interactions, exchanges and interpersonal communication situations are now at the heart of job achievement (Giordano 2016). At the same time, the development of professional networks and their role in the evolution of people's trajectories and careers (Arthur and Rousseau 1996) has reinforced this relational dimension of work and extended it beyond the company's boundaries (Chia 1995). However, as we have emphasized above, the link with others and interaction are central dimensions in the definition of spirituality and the spiritual dimension of human activity.

In parallel, the modes and forms of involvement in the workplace have also changed. Elements such as emotions, feelings, relational capacities, creativity, reactivity, resistance, have been increasingly solicited and mobilized (Driver 2008, Schreuder\& Coetzee 2011, Guo\& Anderson 2018). To be competent and efficient in a post-modern organization is no longer, or not only, to be able to perform tasks and understand and follow instructions. Above all, it means being able, in interaction with others, to react effectively to situations that occur in a chaotic manner (Gleick, 1987, Simard et al. 2018) and that are constantly renewed (Dooley 1997).

As Fourie (2014) points out, the individual is thus led to invest in professional activity not simply as a body or brain but as a whole person (Sparrow \& Knight 2006, Schreuder\& Coetzee 2011, Fry\&Geigle 2014).

Finally, the importance of these developments would be reinforced by those of the functioning of society and lifestyles. Several authors point out that secularization (e.g. Weaver and Agle 2002, 
Ashforth\&Vaidyanath 2002, Bogdanova et al. 2017), the transition from the extended family model to the nuclear family model (Fogel 2017, Anna 2017) as well as the increase in company presence time (Rifkin 2004, Galinsky et al. 2005, Blyton et al. 2017) and the development of new forms of involvement (Reichers 1985, Kaur 2017) have placed work at the center of people's lives(Fairholm 1996, Meda 1996, Kossek 2016). For some authors (e.g. Brown \& Lent 2013 or Hall \& Willoughby 2016) this gives work an essential role in researching and defining the meaning of activity, and more generally the meaning of existence. For Grotsis\&Kortezi 2008, these developments give work its spiritual dimension. However, paradoxically, at the same time, the constraints on carrying out the work would be multiplied and reinforced. While, as underlined above, the completion of the tasks require more and more reactivity, inventiveness and interaction, its management would have become more and more constraining. Injunctions to comply with performance standards defined most often in relation to external references to the work situation would have multiplied. Management would have focused on short-term performance, measurement by ratios and the individualization of the evaluation of the contribution to value creation. This would make the work situation a stressful, risky and inhibiting environment for individuals (Karasek and Theorell 1990, Karakas 2010, Dreyer \&Hermans 2014, Anthony-McMann et al. 2017).

In summary of these elements we can underline that the evolution of companies, their organizational and managerial functioning as well as the modes of involvement of individuals, would reinforce the need of people to give meaning to their professional activity. The inability of companies to respond would have shifted this responsibility onto the job. This would have been further reinforced by the weakening of institutions that traditionally fulfilled this role as providers of meaning, such as the family or religions (Van Tonder\&Ramdass 2009). At the same time, work has become the core activity of individuals, in which they are increasingly led to invest themselves as individuals, no longer leaving at the company's door that which makes them unique (Fry \&Geigle 2014).

Work thus becomes a spiritual activity in the sense that, by referring to the three dimensions of spirituality previously identified, it is through this activity that the individual can contribute to something that transcends him, can connect and interact with others and, finally, can accomplish something that gives him satisfaction (Gotsis and Kortezi 2008).

The question of spirituality at work arises at the level of individuals (Mitroff and Denton 1999). Each individual gives his activity and his behavior their (possible) spiritual dimension. The issue would therefore be that of diversity, intrinsic to individuals, and its acknowledgement in the functioning of organizations (Hicks 2002).

\section{SPIRITUALITY AT WORK: A DiVERSiTy MANAGEMENT ISSUE?}

As we have expressed them, questions related to spirituality in the workplace arise in terms of taking diversity into account. The question of spirituality amounts to raising the question of the legitimacy of behavior at work which is not only instrumental but also driven by the employee's quest for personal meaning. How does spirituality impact the functioning of the company and the execution of the work? How can this notion and the theoretical and practical challenges it represents, taking into account an intrinsic diversity, help to understand the stakes of work, its organization and labor relations in postmodern organizations?

We identify two first approaches in the scientific literature to provide answers. The first corresponds to a functional approach (2.1). It raises the question of the link between spirituality and improvement of the functioning of the organization. It explores how the latter and its management can mobilize people's spirituality to improve their well-being and/or performance.

The second approach proposes a reorganization of the company based on taking into account the spiritual dimension of work (2.2). A third approach to these issues brings together critical contributions (2.3).

\subsection{What Impact does Spirituality at Work have on the Functioning of the Organization and Performance?}

An important part of the work on spirituality in the workplace has focused on the impact on the performance and the functioning of the organisation of taking into account the spiritual dimension of work and what is identified as the need of employees to give meaning to their activity (Jurkiewicz and Giacalone 2004, Jurkiewicz and Giacalone 2004, Benefiel et al. 2014, Fourie 2014, Van der Walt 2018). Two approaches stand out. 
The first approach groups together research that seeks to identify and define the implications of taking spirituality into account in the functioning of the organization and management practice (Jurkiewicz and Giacalone 2004, Gotsis and Kortezi 2008, Vitell 2009, Karakas 2010, Kutcher et al. 2010, Fourie 2014, Naidoo 2014, Wallace et al. 2017). Thus, for example, Karakas (2010) identifies three major outcomes of opening the workplace to employees' spiritual investment. These are employee-centered issues but, according to the author, they have a long-term impact on labor productivity and performance.

The first challenge is to improve the well-being and quality of life of employees. Setting up programmes in companies to encourage people's spiritual investment in their work (for example by encouraging the practice of mediation) would improve happiness, self-esteem or even the optimism of employees (Milliman et al. 2003, Reave 2005, Pawar 2016) and this would also have an impact on stress resistance, job satisfaction and involvement (Paloutzian et al. 2003, Reave 2005, Krishnakumar and Neck 2002, Edward 2005; Faver 2004, Fry 2005). Ultimately, this would improve productivity and reduce absenteeism and turnover (Fry 2005; Giacalone and Jurkiewicz 2003).

The second outcome is that spirituality gives individuals a sense of usefulness and a sense of work. Mitroff and Denton (1999) as well as Giacalone and Jurkiewicz (2003), Gull and Doh (2004) or Afsar and Badir (2017) show that employees who can express their spirituality through their work are more satisfied with it and recognize it as having more meaning, with the result that their involvement, creativity and performance increase.

Finally, the third outcome is the fact that spirituality gives employees a feeling of interdependence and solidarity. (Cavanagh et al. 2001, Duchon and Plowman 2005).

The second approach brings together research aimed at measuring the impact of spirituality, most often understood through the spiritual commitment of employees, on performance in general (Mitroff and Denton 1999, Turner 1999, Thompson 2000, Garcia-Zamor 2003, Fry 2005, Giacalone et al 2005) or in a particular field.

For example, Ghazzawi et al (2016) or Van der Walt (2018) establish a relationship between spirituality and commitment to work. Vitell (2009) makes the link between spirituality and the quality of decision-making by managers and executives. Walker (2013) measures the impact of the ability to reconcile spirituality, religiosity and professional practice on job satisfaction and professional commitment. Still using the same type of approach, Pawar (2016) makes the link with employees' health and well-being, Duffi (2006) or Anvari et al. (2017) with mobility and career decisions, Phipps (2012) or Wallace et al (2017) with managerial effectiveness and leadership, Afsar\&Badir (2017) with innovation, etc.

\subsection{Rethink the Organization of Work Based on the Notion of Spirituality?}

Based on these links between spirituality and religiosity on the one hand and quality of life at work for employees, labor productivity and company performance on the other, some studies propose to rethink the functioning of the organization based on the notions of spirituality of work, people and diversity (Howard 2002, Hicks 2003, Gotsis and Kortezi 2008 Dreyer and Hermans 2014, Benefiel, Fry and Geigle 2014, Miller and Ewest 2015). In this perspective, Benefiel et al (2014) consider that research on spirituality in the workplace gives rise to a new paradigm for thinking about work, its organization and the role and place of people in the company. Douglas Hicks' $(2002,2003)$ writings in particular propose to rethink these elements by starting from the notion of respect for diversity and pluralism.

While refusing to distinguish between religiosity and spirituality at work, Hicks (2002, 2003) establishes three axioms that together form the anthropological basis from which he develops his approach to "spiritual organization". The first axiom is the intrinsic dimension of human spirituality. The search for the meaning of life and activity, for interconnection with others, for transcendence, which are the motors of spirituality, are also the motors driving behavior and action. Moreover, this spiritual dimension of the human being is not reserved to certain individuals. It is both shared by all and specific to each. This is the second axiom: spirituality is as universal as it is infinitely plural. The spiritual process is unique to each person. It can of course follow the precepts and prescriptions of a religion but can also be singular. The third axiom is constituted by the idea that the individual comes to work and acts as a whole person. The identity of the person cannot be fragmented. Spirituality, which is a constitutive element, cannot be left aside... or left at the door of the workplace. 
Based on these elements, Hicks (2003) defines what a spiritual work organization would be as an organization that "recognizes that employees have an inner life that nourishes and is nourished by many fields, including meaningful work, all in the context of community". Spiritual organization would thus be an organization in which people (colleagues, subordinates, managers, etc.) are recognized as distinct individuals by everyone and in which formal or informal organizational modes of functioning take this diversity into account, respect it and consider and value everyone as a person.

Hicks' $(2002,2003)$ approach is not instrumental but conceptual. For him, it is not a question of providing the company with tools to stimulate the spiritual activity of employees, such as rooms and organized meditation sessions, reflection groups on meaning or even by instituting moments of silent introspection before meetings. On the other hand, it is a question of proposing a framework for rethinking the modes of organization and functioning of the company (decision-making processes, work distribution, manager-managed relations, etc.) based on the model of the person at work formed by the three axioms described above.

\subsection{Critical Approaches}

These first approaches to spirituality in the workplace are not without question. For Lips-Wiersma et al (2009), Driver (2007) or Bell and Taylor (2004) for example, papers proposing to rethink work and relationships at work based on the notion of "whole person" could lead to finalizing the work in relation to the individual himself and no longer in relation to the dynamics of interaction within teams as well as in relation to the activities and projects of the company. Moreover, for Straus and Swayerr (2009) as for Cash and Gray (2000) this notion raises the question of the limits of what can be accepted in the name of respect for people and their freedom. Are all behaviors acceptable as long as they are expressions of personality and individual freedom? Focusing on the approaches that link the spirituality of individuals to their impact on the situation of these individuals and on the functioning and performance of the company, Dent, Higgins and Wharff (2005), Lambert (2010) as well as Schutte (2016) emphasize that there is a debate on how to mobilize results. Should they be tools for companies and managers to guide their mobilization of employee spirituality at work? Should they rather serve critical approaches? From this critical perspective, we distinguish in our literature review two main axes of development. The first is centered on the limits of functionalist work. The second is centered on the risks linked to the mobilization of the notion of spirituality by companies.

The first axis of development of critical approaches is therefore that of highlighting and analyzing the limits of the research on the links between the spirituality of employees and the way work is organized.

The main argument in the literature concerns the definitions of spirituality, and to a lesser extent of religiosity, which are mobilized in some studies. As we have pointed out in the first part of this article, they are very diverse and none would seem to serve as a universal point of reference. Milliman et al. (2003) or Markow and Klenke (2005) further point out that definitions of spirituality are broad and often refer to notions such as well-being (deKlerk 2005), joy (Giacalone and Jurkiewicz 2003, Reave 2005) or ethics and morals (Issa and Pick 2011, McCormick 2013) or even "good behavior" or involvement. For Hicks (2002) the notion of spirituality thus became in some cases so encompassing that it amounts to covering all questions of organization, management and life at work. For Casey (1999), Driver (2005) or Lips-Wiersma et al (2009) another consequence of the way spirituality is approached in literature is that it induces in certain papers a systematically positive orientation and promotion of taking it into account to organize work.

Yet, as several researchers (e.g. Higgins, \&Wharff, 2005, Hayden and Barbuto 2011) point out, the stakes are high on at least two levels. First of all, it concerns the credibility of the question of spirituality at work as an object of research (Hicks 2002) and also the challenge for companies and their managers. Indeed, for Driver (2005), Karakas (2010) as well as for Schutte (2016), the absence of stable and common definitions of central notions would explain the absence of shared theoretical and methodological frameworks. This would limit the accumulation of empirical work whose results would be truly comparable and articulable (Sprung et al. 2012) and which would allow real progress in knowledge on these issues (Lips-Wiersma et al. 2009). This would also explain the difficulty of the topic in being taken seriously by practitioners (Driver 2005). Yet there are methodological tools for measuring spirituality, as well as religiosity at work, that provide referential measures. We mentioned earlier the STS and FWS scales which are applied in a significant number of research papers on these subjects (e.g. Walker 2012, Ayoun et al. 2014). 
The second critical argument present in the literature is the analysis of the risks of harnessing the notion of spirituality to organize work and guide managerial action, what Lips-Wiersma, Dean and Fornaciari (2009) call the dark side of spirituality at work. Based on an analysis of the literature, the authors identify control and instrumentalization as the two main risks linked to the use of notions of spirituality and religiosity in organizations and by management. In their approach, spirituality at work, because it is based on the principle of giving individuals the means to find meaning in their activity in the company, can block any critical scrutiny. Indeed, people are not invited to change the organisation and work. On the contrary, they are invited to think about the meaning of this organisation and this work in such a way as to make them (at a minimum) compatible with their lives and aspirations. For the authors, the risk of instrumentalization is intrinsic to the functioning of organizations that are by nature instrumental. It is that the mobilization of employee spirituality is seen as a means of achieving a specific operational goal rather than a means of recognizing them as individuals.

These risks of instrumentalization and control are used by Lips-Wiersma, Dean and Fornaciari (2009) to construct a matrix and to identify four configurations each corresponding to a distorted and negative use of spirituality at work: seduction, manipulation, evangelization and enslavement.

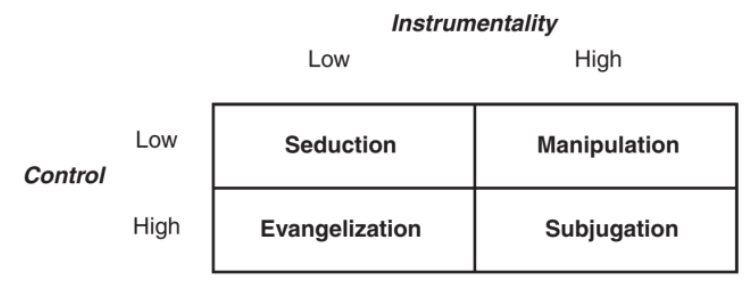

\section{Discussion: The Pretence of Promoting Spirituality in the WorkPlace}

\subsection{A Spirituality that is necessarily Non-Religious?}

Many authors, especially when developing their work with what we have called functional approaches, distinguish religiosity and spirituality and do not give them the same place and legitimacy in the workplace (Mitroff et al 1999, Mitroff 2003, McLaughlin, 2005, Hayden \&Barbuto 2011, Phipps 2012, Benefel, Fry and Giegle 2014). The spiritual dimension of people's religious commitment is obviously recognized. However, as Hicks (2002) points out, for many authors religion is associated with negative characteristics such as dogmatism, rigidity or the risk of proselytism. As a result, religious behaviors, which are mostly behaviors that reflect people's religiosity (it is more often the wearing of a religious sign than proselytism (SHRM (2017)) are viewed with defiance in many writings that are also very often real pleas for spirituality at work (e.g. Mitroff 2003). There is here a double paradox which is well identified by some authors (e.g. DiPadova 1998, Cash and Gray 2000, Weaver and Agle 2002a and 2002b).

First of all, the quest for transcendence is, as most attempts to define spirituality affirm (Piemont 1999, 2001 and 2007, Giacalone and Jurkiewicz 2003, Gotsis and Kortezi 2008, Schutte 2016), one of the structuring elements of the spiritual process. Moreover, this approach is also systematically defined in the literature as individual and singular (Piedmont 2001). It is specific to each employee. Some even argue that it cannot be forced and/or imposed (Mitroff 2003). Yet the quest for transcendence is at the very heart of religion and religious practice. The spiritual process would therefore be free and personal... unless it follows the path of religion.

Then, both functional approaches and those advocating a redesign of work, work relations and organization based on a spiritual anthropology and paradigm put the notion of the whole person at the heart of the approach (Fairholm 1998, Mitroff and Denton 1999, Mitroff 2003, Fourie 2014). The authors stress the need to consider the whole person at work. They also emphasize the principle that spirituality cannot be left at the door of the enterprise (Wiersma 2002). As Hayden and Barbuto (2011) or Hicks (2002) point out, it is difficult to imagine what argument could then be given to an employee whose spirituality is religious to ask him to give up being fully invested in his professional activity as a person.

\subsection{A Reversal of Responsibility?}

The question of taking into account the intrinsic diversity that employee spirituality represents, as it is perceived by part of the literature and through certain corporate practices, also raises questions. In fact, as underlined by Lips-Wiersma, (2002 and 2003), Lips-Wiersma et al. (2009) and Karakas 
(2010), once it has been observed that the post-modern enterprise generates stress, overwork and addiction to work, impoverishment of the meaning of work and of employee involvement (etc.), a consequent number of research papers advocate as a solution the mobilization of the spirituality of the employees as well as the setting up of an organizational functioning and a managerial practice which not only allow spirituality but also favor it (e.g. Ashmos and Duchon 2000, Garcia-Zamor 2003, Giacalone and Jurkiewicz, 2003, Fry 2005, Afsar et al. 2017, González-González 2018). Here again, there is a paradox but also the risk of a reversal of responsibility and a perversion of the logic of liberal enterprise.

The paradox lies in the fact that asking the employee to invest his spirituality in work leads to strengthening the centrality of work in his life. This further increases the weakening of the role played by other socialization circles and other ties (family, friends, community, etc.). This further increases his vulnerability to the evils of post-modern work. Contrary to what some authors often cited for this in the literature (e.g. Gotsis\&Kortezi 2008) argue, the spiritual dimension of work did not emerge in the 1980s. Without going back too far we can at least refer to the writings of the philosophers Hannah Arrendt (1958) and Simone Weil (1951). With very different approaches, each of them highlighted this spiritual dimension of work and the importance of work in people's lives. But each of them also stressed that the meaning of life and the human condition are not reduced to work only.The relationship to transcendence in particular, whether it is viewed within the framework of religion or an existentialist movement, would not be defined and lived with the boundaries of the company and its economic objectives as its limits.

Beyond that, functionalist approaches operate a reversal of responsibility. The project of certain companies and certain ways of operating and organizing work are presented as no longer carrying meaning. But the proposed solution is not to ask these companies to provide meaning again. It is to ask them to give their employees the means to find meaning for themselves in their participation in the operation, in the implementation of strategies, in the pursuit of objectives often reduced to a financial dimension. As both Lips-Wiersma et al (2009) and Bell and Taylor (2004) point out, it is up to them to find ways to make their working lives bearable and meaningful and, since the company offers them nothing transcendent, to transcend themselves in order to remain effective. This is not illegitimate; on the contrary, the role of the liberal enterprise is not primarily to make a profit. It is the entrepreneur's initiative to implement a project that will make the world move forward. It is also to offer people, employees, to join in this quest for progress by contributing actively and as a whole person through their work.

\section{CONCLUSION}

Spirituality in the workplace raises the question of taking diversity into account. Whether religious or not, spirituality is a dimension of man and therefore it is also expressed through work. Whatever its form (salaried employment, entrepreneurship, voluntary work, etc.), professional activity is central to most people's lives and is one of the preferred ways of participating in the functioning of the world.

Approaches to spirituality issues in the workplace are diverse. Some propose that this notion of diversity be used to found a new anthropology to study work and design a business model that takes employees into account as people and not simply as productive resources. Others develop a critical analysis of the work carried out in this field and especially of the possible deviations of the mobilization of these notions by companies and management. Finally, others, the most numerous, try to link the spirituality of the individual, the realization of the work and the functioning of the company. We have highlighted the questions and paradoxes that the latter approaches raise. Drawing on the critical literature about this topic, we have also highlighted their conceptual and methodological weaknesses, which are largely related to the difficulty of clearly stating what spirituality is and how it can be measured, as well as of identifying and quantifying its effects on work. It seems to us that the major problem with these approaches is the wrong entry point. Rather than starting from the individual and asking the question of his spirituality, it is better to ask the question of the concrete functioning of the enterprise (both strategic and decision-making as well as operational and productive) and of the concrete work. How does the concrete, what really happens in work situations, bring into play the transcendence, the relationship with others or the sense of each person's involvement? How in day-to-day business as in the longer term does the company and its organization involve individuals while respecting their diversity of positions, modes of action, aspirations and personality? 


\section{REFERENCES}

[1] Afsar B \&Badir Y. (2017), "Workplace spirituality, perceived organizational support and innovative work behavior." Journal of Workplace Learning.; 29(2):95-109.

[2] Anna, M. (2017)."From post-traditional to post-modern family - contemporary models of family relations".Wychowanie W Rodzinie ,Vol III, Iss 3/2011, Pp 55-84 (2017), (3/2011), 55

[3] Anthony-McMann, P. E., Ellinger, A. D., Astakhova, M., \&Halbesleben, J. B. (2017).“Exploring Different Operationalizations of Employee Engagement and Their Relationships With Workplace Stress and Burnout". Human Resource Development Quarterly, (2), 163.

[4] Anvari, R., Barzaki, A. S., Amiri, L., Irum, S., \&Shapourabadi, S. (2017). "The mediating effect of organizational citizenship behavior on the relationship between workplace spirituality and intention to leave".Intangible Capital, 13(3), 615-639.

[5] Arendt H. (1958), The human condition, Universty of Chicago Press.

[6] Arthur M. et Rousseau D. (1996), The boundarylesscareer: a new employment principle for e new organizational era, (coord. Par), Oxford University Press.

[7] Ashforth, B. E., \&Vaidyanath, D. (2002). Work organizations as secular religions. Journal of Management Inquiry, 11, 359-370.

[8] Ashmos, D.P. and Duchon, D. (2000), "Spirituality at work: a conceptualization and measure", Journal of Management Inquiry, Vol. 9 No. 2, pp. 134-145.

[9] Ayoun B., Rowe L. et Yassine F., (2014), “Is workplace spirituality associated with business ethics?”, International Journal of Contemporary Hospitality Management. Vol. 27 No. 5, 2015 pp. 938-957

[10] Bailey, J. R. (2001). Book review of J.A. Conger \& associates, Spirit at work: discovering the spirituality in leadership. Leadership Quarterly, 12, 367-368.

[11] Batson, C. D., \&Schoenrade, P. A. (1991a). Measuring religion as quest: Reliability concerns. Journal for the Scientific Study of Religion, 30, 430- 447

[12] Batson, C. D., \& Ventis, W. L. (1982). The religious experA social-psychological perspective. New York: Oxfo Unive

[13] Batson, C. D., Schoenrade, P., \& Ventis, W. L. (1993). Religion and the individual: A social-psychological perspective. Oxford: Oxford University Press.

[14] Bell, E., \& Taylor, S. (2004). 'From outward bound to inward bound': The prophetic voices and discursive practices of spiritual management development. Human Relations, 57, 439-466.

[15] Bell, M. P. (2007). Diversity in organizations. Mason, OH: Thomson-South Western

[16] Benefel, M., Fry, L.W. \&Giegle, D., (2014), 'Spirituality and religion in the workplace: History, theory, and research', Psychology of Religion and Spirituality 6(3), 175-187.

[17] Blyton P.,Hassard J., Hill S. \&Starkey K., (2017), Time, Work and Organization, Routledge

[18] Bogdanova, O. A., Lipchanskayal, I. V., Plotnikoval, T. V., \&Shtofer, L. L. (2017). "Specific Features of Secularization in the Modern Western Culture".European Research Studies, (3B), 34.

[19] Brenner MH, Andreeva E, Theorell T, Goldberg M, Westerlund H, Leineweber C, et al. (2014), “ Organizational Downsizing and Depressive Symptoms in the European Recession: The Experience of Workers in France, Hungary, Sweden and the United Kingdom". PLoS ONE 9(5): e97063. https://doi.org/10.1371/journal.pone.0097063

[20] Brown, S.D. \& Lent, R.W., (2013), 'Understanding and facilitatng career development in the 21st century', in S.D. Brown \& R.W. Lent (eds.), Career development and counseling. Putng theory and research to work, 2nd edn., pp. 1-28, John Wiley \& Sons Inc., New Jersey

[21] Burke W.W. (2017), Organization change: Theory and practice, Sage

[22] Casey, C. (1999). "Come and join our family": Discipline and integration in corporate organizational culture. Human Relations, 52,155-178

[23] Cavanagh, G., Hanson, B., Hanson, K., and Hinojoso, J.: (2001), Toward a Spirituality for the Contemporary Organization: Implications for Work, Family and Society, in Champoux, J.E. (2000). Organizational behavior: Essential tenets for a new millennium. South-Western College Publishing, Cincinatti

[24] Cavanagh, G.: (1999), Spirituality for managers: context and critique. Journal of Organizational Change Management.12(3), 186

[25] Chia R. (1995), "From Modern to Postmodern Organizational Analysis", Organization Studies, Vol 16, Issue 4, pp. 579 - 604

[26] CJUE (2017),ttps://curia.europa.eu/jcms/upload/docs/application/pdf/201703/cp170030fr.pdf

[27] Cooper R. (2015), «Information, Communication AndOrganisation: A Post-structural Revision », Parker M. \& Gibson Burrell G., (2015), For Robert Cooper, (eds.), Routledge. 
[28] Courpasson D. et Golsorkhi D. (2011). «Power and Resistance: Variations on "what's going on politically in and around organizations?”.M@N@Gement, (1), 2. doi:10.3917/mana.141.0002

[29] deKlerk, J. J., (2005), 'Spirituality, Meaning in Life and Work Weuness: A Research Agenda', International Journal of Organisational Analysis 13(1), 64-88

[30] Dent, E. B., Higgins, M. E.,Wharff, D. M., (2005), "Spiritua

[31] DiPadova, L. N.: 1998, "The Paradox of Spiritual Management: Cultivating Individual and Community Leadership in the Dilbert Age", Journal of Management Systems 10, 31-46.

[32] Dooley, K. (1997), A complex adaptive systems model of organization change. Nonlinear Dynamics, Psychology and the Life Sciences, Vol. 3, 230-249.

[33] Dreyer, J.S. \&Hermans, C.A.M., (2014), 'Spiritual character traits and leadership in the school workplace: An exploraton of the relatonship between spirituality and school leadership in some private and religiously afliated schools in South Africa', Koers - Bulletn for Christan Scholarship 79(2), Art. \#2136, 9 p.

[34] Driver, M. (2005).From empty speech to full speech?Reconceptualizing spirituality in organizations based on a psychoanalyticallygrounded understanding of the self. Human Relations, 58,1091-1110.

[35] Driver, M. (2008). "New and useless: A psychoanalytic perspective on organizational creativity." Journal Of Management Inquiry, 17, 187-197

[36] Duchon, D., \& Plowman, D. A. (2005).Nurturing the spirit atwork: Impact on work unit performance.Leadership Quarterly, 16, 807-833

[37] Edward, K.-I. (2005). The phenomenon of resilience in crisis caremental health clinicians. International Journal of Mental HealthNursing, 14, 142-148

[38] Ekstedt E. (1999), Neo-Industrial Organising: Renewal by Action and Knowledge Formation in a ProjectIntensive Economy, RoutledgeNew York,

[39] Fairholm, G. W.: (1996), Spiritual leadership: fulfilling whole-self needs at work. Leadership and Organization Development Journal. Vol. 17 (5 ); pp. 11-17

[40] Fairholm, G.W. (1996), "Spiritual leadership: fulflling whole-self needs at work", Leadership and Organization Development Journal, Vol. 17 No. 5, pp. 11-17

[41] Faver, C. A. (2004). Relational spirituality and social caregiving.Social Work, 49, 241-250.

[42] Fogel S. (2017), « Nuclear Family », Publishers Weekly, (18). 34.

[43] Fourie, M., (2014), 'Spirituality in the workplace: An introductory overview', In die Skriflig 48(1).

[44] Fry, L., \& Cohen, M. (2009). Spiritual leadership as a paradigm for organizational transformation and recovery from extended work hour cultures. Journal of Business Ethics, 84, 265-278

[45] Fry, L.W.: (2005), Toward a theory of ethical and spiritual well-being, and corporate social responsibility through spiritual leadership. In: C. Dunne, R.A. Giacolone and C.L. Jurkiewicz, Editors, Positive psychology and corporate responsibility, Information Age Publishing, Greenwich, CT

[46] Galinsky, E., Bond, J.T., Kim, S.S., Backon, L., Brownfield, E., \& Sakai, K.: (2005), Overwork in America: When the way we work becomes too much. New York: Families and Work Institute.

[47] Garcia-Zamor, J.: (2003), Workplace Spirituality and Organizational Performance. Public Administration Review. Vol. 63 (3), pp. 355-363.

[48] Ghazzawi I, Smith Y. et Cao Y. (2016), "Faith and job satisfaction: is religion a missing link?”,Journal of Organizational Culture, Communications and Conflict, Volume 20, Number 1.

[49] Ghazzawi, I.A. and Smith, Y. S., (2009) Crafting the whole employee: Job satisfaction, job commitment, and faith. The Business Review, Cambridge, 1(2), 300-309

[50] Giacalone, E. \&Dafna R. A.: (2000), The development of new paradigm values, thinkers, and business: Initial frameworks for a changing business worldview, The American Behavioral Scientist; Thousand Oaks; 43 (3), 1217-1230.

[51] Giacalone, R. A., \&Jurkiewicz, C. (2003).Toward a science of workplace spirituality. In R. A. Giacalone\& C. Jurkiewicz (Eds.),Handbook of workplace spirituality and organizational performance (pp. 3-28). Armonk: M.E. Sharpe.

[52] Giordano Y. (2016). "Around the Communicative Constitution of Organizations Perspective" Cooren, F., Vaara, E., Langley, A., \&Tsoukas, H. (Eds.) (2014) Language and communication at work: Discourse, narrativity and organizing. Oxford, UK: Oxford University Press

[53] Glasner P., (1977). - The sociology of secularisation. A critique of a concept, London, Routledge\&Kegan Paul.

[54] Gleick, J.: (1987), Chaos: Making a new science. New York: Viking. Glock\& Stark, 1965

[55] Glock, C. Y. (1959). “The sociology of religion”. In R. Merton L. Bloom, \& L. Cottrell (EdsProblems and prospects, New york, Basic Books. 
[56] Glock, C. Y. (1962), “On the study of religious commitment" Religious Education, 57(Research Supplement): S98- S110.

[57] Gomez P.Y. etKorine H. (2005), 'Democracy and the Evolution of Corporate Governance', Corporate Governance: An International Review, no. 6, p. 739

[58] Gotsis, G. and Kortezi, Z. (2008), "Philosophical foundations of workplace spirituality: a critical approach", Journal of Business Ethics, Vol. 78 No. 4, pp. 575-600.

[59] Gull, G. A., and Doh, J.: (2004), The "Transmutation" of the Organization: Toward a More Spiritual Workplace. Journal of Management Inquiry.13(2), 128.

[60] Guo S.J. \& Anderson L.B., (2018), "Workplace adversity and resilience in public relations: Accounting for the lived experiences of public relations practitioners", Public Relations Review, https://doi.org/10.1016/j .pubrev.2018.02.002

[61] Hall, S. S., \& Willoughby, B. J. (2016). "Relative Work and Family Role Centralities: Beliefs and Behaviors Related to the Transition to Adulthood". Journal Of Family And Economic Issues, (1), 75.

[62] Harman, W., and Hormann, J. (1990), Creative work, the constructive role of business in a transforming society. Indianapolis, IN: Knowledge Systems.

[63] Hatch M. etCunlife A. (2013), Organization theory: modern, symbolic and postmodern perspectives, Oxford University Press.

[64] Hatch M.J. (2018), Organization theory: Modern, symbolic, and postmodern perspectives, Oxford University Press.

[65] Hayden R. W. and Barbuto, Jr J. E., (2011), « Expanding a Framework for a Non-Ideological Conceptu alization of Spirituality in the Workplace » Journal of Behavioral \& Applied Management, p.142-155.

[66] Hicks, D. A. (2002).Spritual and religious diversity in the workplace. Implications for leadership. Leadership Quarterly, 13, 379-396

[67] Hicks, D. A. (2003), Religion and the Workplace: Pluralism, Spirituality, Leadership. Cambridge University Press

[68] Hirschhorn L. (1998). Reworking Authority: Leading and Following in a Post-Modern Organization.The MIT Press.

[69] Howard, S.: (2002), "A spiritual perspective on learning in the workplace", Journal of Managerial Psychology, Vol. 17, no. 3, pp 230-242. MCB University Press.

[70] Hyman C. et Handal P.J. (2006), Defnitions and evaluations of religion and spirituality items by religious professionals : a pilot study, Journal of religion and health, vol.45, p. 264-282.

[71] Issa, T. and Pick, D. (2011), “An interpretive mixed-methods analysis of ethics, spirituality, and aesthetics in the Australian services sector", Business Ethics: A European Review, Vol. 20 No. 1, pp. 45-58.

[72] Jurkiewicz C. etGiacalone R. (2004), A values framework for measuring the impact of workplace spirituality on organizational performance. Journal of Business Ethics, Vol. 49, n 2, p. 129-142

[73] Karakas F. (2010), Spirituality and performance in organizations: a literature review, Journal of Business Ethics, n94, Vol.1, p. 89-106

[74] Karasek, R. and Theorell, T. (1990), Healthy Work: Stress, Productivity, and the Reconstruction of Working Life. Basic Books.

[75] Kaur, S. (2017). “Antecedents and Consequences of Employee Engagement: A Literature Review”. IUP Journal Of Organizational Behavior, 16(3), 7-32

[76] Kennedy, H. K. (2001), Spirituality in the workplace: An empirical study of this phenomenon among adult graduates of a college degree completion program. Nova Southeastern University.

[77] Kinjierski, V. M. et B. J. Skrypnek (2004), 'Defining Spirit at Work. Finding Common Ground', Journal of Organizational Change Management 17(3), 165-182.

[78] Kossek, E. E. (2016). "Managing work-life boundaries in the digital age".Organizational Dynamics, 45, 258-270.

[79] Krishnakumar, S. and Neck, C. P.: 2002, The "what", "why" and "how" of spirituality in the workplace. Journal of Managerial Psychology. Vol. 17 (3), 153-164.

[80] Kutcher, E.J.; Bragger, J.D.; Rodriguez-Srednicki, O. and Masco, J.L. (2010).The role of religiosity in stress, job attitudes and organizational citizenship behavior.Journal of Business Ethics 95:3, pp. 319-337

[81] Lambert (2010), God goes to the office, Knoxville News Sentinel, p. 7A.

[82] Lips-Wiersma M. et Morris L. (2009), Discriminating between 'meaningful work' and 'the management of meaning, Journal of Business Ethics, vol.88, p. 491-511.

[83] Lips-Wiersma, M.: 2002, Analysing the career concerns of spiritually oriented people: Lessons for contemporary organizations. Career Development International, 7(6/7), 385. 
[84] Lips-Wiersma, M.: 2003, Making Conscious Choices in Doing Research on Workplace Spirituality, Journal of Organisational Change Management Vol. 16 (4), pp. 406-425.

[85] lity and Leadership: An Empirical Review of Definitions, Distinctions, and Embedded Assumptions". The Leadership Quarterly.Vol. 16 (5).

[86] Liu C.H. et Robertson P.J. (2012), Spirituality in the workplace : theory and measurement, Journal of Management Inquiry, vol.20, p. 35-50.

[87] Lynn, M. L., Naughton, M. J., \&VanderVeen, S. (2009). Faith at work scale (FAW): Justification, development, and validation of a measure of Judaeo-Christian religion in the workplace. Journal of Business Ethics, 85, 227-243.

[88] Markow, F. Klenke, K.: 2005, The effects of personal meaning and calling on organizational commitment: An empirical investigation of spiritual leadership. International Journal of Organizational Analysis. Vol. 13 (1), pp. 8-27.

[89] McCormick, D.W. (2013), "The future of scholarship in management, spirituality, and religion: diversity and the creative nexus", in Neal, J. (Ed.), Handbook of Faith and Spirituality in the Workplace: Emerging Research and Practice, Springer, New York, NY, pp. 717-722

[90] McLaughlin, C. (2005), "Spirituality and ethics in business", European Business Review, Vol. 17, No. 1, pp. 94-101.

[91] Meda, D. (1996). New perspectives on work as value.International Labour Review, 135, 633-644

[92] Miller, D, \&Ewest, T (2015), 'A new framework for analyzing organizational workplace religion and spirituality', Journal Of Management, Spirituality \& Religion, 12, 4, p. 305

[93] Milliman, J., Czaplewski, A. J. and Ferguson, J.: 2003, Workplace spirituality and employee work attitudes: An exploratory empirical assessment. Journal of Organizational Change Management. Vol. 16 (4), pp. 426-447.

[94] Mitroff I. (2003), "Do Not Promote Religion under the Guise of Spirituality", Organization, Volume 10(2): 375-382.

[95] Mitroff, I. I., \& Denton, E. A. (1999).“A study of spirituality in theworkplace”.Sloan Management Review, 40, 83-92

[96] Mitroff, I.I., Denton, E.A. \&Alpaslan, C.M., (2009), 'A spiritual audit of corporate America: Ten years later (Spirituality and atachment theory. An interim report)', Journal of Management, Spirituality and Religion 6(1), 27-41.

[97] Naidoo, M., (2014), 'The potental of spiritual leadership in workplace spirituality', Koers - Bulletn for Christan Scholarship 79(2), Art.\#2124, 8 p.

[98] Neal, J. (2000), Work as service to the divine. American Behavioral Scientist, 12(8), 1316- 1334

[99] Palley T. (2016), Financialization: the economics of finance capital domination, Springer

[100] Paloutzian, R.F. Emmons, R.A. and Keortge, S.G.: (2003), Spiritual well-being, spiritual intelligence, and healthy workplace policy. In: R.A. Giacolone and C.L. Jurkiewicz, Editors, Handbook of workplace spirituality and organizational performance, M.E. Sharpe, New York pp. 123-137.

[101] Parker M. \& Gibson Burrell G., (2015), For Robert Cooper, (eds.), Routledge.

[102] Pawar BS. (2016), "Workplace spirituality and employee well-being: An empirical examination." Employee Relations.;38(6):975-994.

[103] Phipps, K.A., (2012), 'Spirituality and strategic leadership: The influence of spiritual beliefs on strategic decision making', Journal of Business Ethics 106, 177-189.

[104] Piedmont, R.L. (1999), "Does spirituality represent the sixth factor of personality? Spiritual transcendence in the fve-factor model”, Journal of Personality, Vol. 67 No. 6, pp. 985-1013.

[105] Piedmont, R.L. (2001), "Spiritual transcendence and the scientifc study of spirituality", Journal of Rehabilitation, Vol. 67 No. 1, pp. 4-11.

[106] Piedmont, R.L. (2007), "Cross-cultural generalizability of the spiritual transcendence scale to the Philippines: spirituality as a human universal”, Mental Health, Religion \& Culture, Vol. 10 No. 2, pp. 89- 107.

[107] Ray, M., and Rinzler, A. (Eds.), (1993), The new paradigm in business. New York: Tarcher.

[108] Reave, L. (2005), Spiritual values and practices related to leadership effectiveness. The Leadership Quarterly.Vol. 16 (5), 655-687

[109] Reichers A.E. (1985), «A Review and Reconceptualization of Organizational Commitment », Academy of Management Review, vol. 10, $\mathrm{n}^{\circ} 3$, p. 465-476.

[110] Rifkin, J.: 2004, The European Dream. New York: Tarcher/Penguin.

[111] Schreuder, A.M.G. \& Coetzee, M., (2011), Careers: An organisatonal perspectve, $4^{\text {th }}$ edn.,Juta and Company Ltd., Claremont. 
[112] Schutte, P.J.W., (2016), 'Workplace spirituality: A tool or a trend?',HTS Teologiese Studies/Theological Studies 72(4)

[113] SHRM (2017), "Leave for religious observances", Rapport SHRM, Winter.

[114] Simard M., Aubry M. \&Laberge D., (2018), "The utopia of order versus chaos: A conceptual framework for governance, organizational design and governmentality in projects", International Journal of Project Management, Volume 36, Issue 3, April, Pages 460-473

[115] Sparrow, T. \& Knight, A., (2006), “Applied EI: The importance of attiudes in developing emotonal intelligence", Jossey-Bass, England

[116] Sprung J.M., Sliter M.T. etJexS.m. (2012), "Spirituality as a moderator of the relationship between workplace aggression and employee outcomes", Personality and Individual Differences 53 (2012) 930934

[117] Stark, R., \&Glock, C. Y. (1968).American piet religious commitment. Berkeley: University Press.

[118] Steenkamp, P.L. \&Basson, J.S., 2013, 'A meaningful workplace: Framework, space and context', HTS Teologiese Studies/Theological Studies 69(1), Art. \#1258, 9 p.

[119] Thompson C. M. (2000), The congruent life: Following the inward path of fulfling work and inspired leadership, San Francisco, Jossey-Bass

[120] Turner, J., (1999), "Spirituality in the workplace”, caMagazine, Vol. 132 No. 10, pp. 41-2

[121] Van der Walt F. (2018). "Workplace spirituality, work engagement and thriving at work". SA Journal Of Industrial Psychology, Vol 44, Iss 0, Pp E1-E10 (2018), (0),

[122] Van der Zwan N. (2014), "Making sense of financialization”, Socio-Economic Review, Volume 12, Issue 1, January, Pages 99-129

[123] Van Tonder, C.L. \&Ramdass, P., (2009), 'A spirited workplace: Employee perspectves on the meaning of workplace spirituality', SA Journal of Human Resource Management/ SA Tydskrifvirmens like hulp bronbestuur7(1), Art. \#207, 12 p.

[124] Vitell, S. J. (2009). The role of religiosity in business and consumer ethics: A review of the literature. Journal of Business Ethics 90, pp.155-167.

[125] Walker A.G., (2013), "The Relationship between the Integration of Faith and Work with Life and Job Outcomes", Journal of Business Ethics, 112:453-461.

[126] Wallace W.A., Hayek B., Haden, S. P., \&Atinc, G. (2017). "Servant leadership and followership creativity. » Leadership \& Organization Development Journal, 38(2), 178-193

[127] Weaver G.R. and Agle B.R., (2002a), «Religiosity and Ethical Behavior in Organizations: A Symbolic Interactionist Perspective », The Academy of Management Review, Vol. 27, No. 1, pp. 77-97

[128] Weaver G.R. etAgle B., (2002b), "Religion in the Workplace: Reaffirming Complexity", The Academy of Management Review, Vol. 27, No. 4 (Oct., 2002), pp. 502-504

[129] Weil S. (1951), La condition ouvrière, Gallimard, Paris.

[130] Wheatley, M. :1992, Leadership and the new science: Learning about organization from an orderly universe. San Francisco: Berrett-Koehler.

[131] Widerszal-Bazyl M. \&and Mockałło Z. (2015), "Do all types of restructuring threaten employees' wellbeing? an exploratory study", International Journal of Occupational Medicine and Environmental Health, 2015; 28(4):689 - 706

Citation: Pr. Lionel Honoré. "The Issues of Spirituality in the Workplace" International Journal of Managerial Studies and Research (IJMSR), vol 6, no. 10, 2018, pp. 33-45. doi: http://dx.doi.org/10.20431/ 2349-0349.0610003.

Copyright: (C) 2018 Authors. This is an open-access article distributed under the terms of the Creative Commons Attribution License, which permits unrestricted use, distribution, and reproduction in any medium, provided the original author and source are credited. 